УДК 373.015.31:172.15

DOI:

Юрій Буклов, аспірант кафедри загальної педагогіки та дошкільної освіти Дрогобицького державного педагогічного університету імені Івана Франка

\title{
ЗМІСТОВІ КОМПОНЕНТИ НАЦІОНАЛЬНО-ПАТРІОТИЧНОГО ВИХОВАННЯ УЧНІВСЬКОЇ МОЛОДІ
}

У статті проаналізовано змістові аспекти національно-патріотичного виховання учнівської молоді, визначено його фундамент (становлення самодостатнього учня-патріота, майбутнього громадянина Украӥни, готового до виконання громадянських і конститучійних обов 'язків); висвітлено основні завдання громадянсько-патріотичного, військово-патріотичного та духовно-морального виховання школярів із метою формування в них національної свідомості та самосвідомості, активної життєвої позиції, навичок спілкування, єдності слова і справи; потреби брати активну участь у розбудові своєї незалежної держави; з'ясовано їх надважливість у сучасних умовах.

Ключові слова: виховання начіонально-патріотичне, громадянсько-патріотичне, військовопатріотичне, духовно-моральне, учнівська молодь.

Jim. 11.

Yuriy Buklov, Postgraduate Student of the General Pedagogy and Preschool Department Drohobych Ivan Franko State Pedagogical University

\section{SEMANTIC COMPONENTS OF NATIONAL-PATRIOTIC EDUCATION OFTHE PUPILS'YOUTH}

The author of the article analyzes the content aspects of national-patriotic education of youth, the foundation of which is the establishment of the self-sufficient pupil-patriot, the citizen of Ukraine, ready to carry out civil and constitutional duties. The author elucidates the basic tasks of civil-patriotic, military-patriotic and spiritual and moral upbringing of pupils, the formation of their national consciousness and selfconsciousness, active living position, rules of cohabitation, unity of words and deeds, readiness to take an active part in the life of their state. The author proves the importance of national-patriotic education of the pupils' youth in modern conditions.

The main purpose of secondary schools in the pupils' youth upbringing is to develop a clear civic position on it; social and patriotic behavior; readiness for the relevant activity in all circumstances; high culture of interpersonal relations; knowledge of the national culture; the formation of the needs to work for the prosperity of the state, the willingness to protect it. The emphasis is placed on the content of patriotic pupils' upbringing as an important component of national education, the formation of a self-sufficient citizen - the patriots of Ukraine, humanitarian and democrat, ready to fulfill civil and constitutional duties, to imitate the rich spiritual and cultural achievements of the Ukrainian people, to a high culture interpersonal relationships.

Modern pupils must not only identify themselves with the Ukrainian people, but also strive to live in Ukraine, build it, serve the Motherland on the path to its national democratic revival; work for its benefit, protect it; respect the laws of the Motherland and adhere to its Constitution; speak a state language; to recognize the priorities of human rights, to respect freedom, democracy and justice. The content of national patriotic education, which is essential in the formation of future responsible citizens of our country, which are able to fight for national identity, forming their own consciousness and self-awareness is need to be widely promoted in schools.

Keywords: national-patriotic education, civil-patriotic, military-patriotic, spiritual and moral education, the pupils' youth.

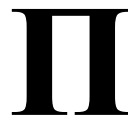
остановка проблеми. Сьогодні в Україні, як ніколи, на часі питання відродження національно-патріотичного виховання дітей і молоді на загальнодержавному рівні. У зв’язку із драматичними подіями на Сході України все більшої актуальності набувають розпочаті після проголошення незалежності суспільно-політичні, економічні й науковопедагогічні дебати стосовно формування національної самосвідомості та громадянського становлення особистості. 3 огляду на означену проблему вітчизняними науковцями розроблено Стратегію національно-патріотичного виховання дітей та молоді на 2016 - 2020 роки, в якій зазначено: "В Україні національно-патріотичне виховання дітей та молоді має стати одним із пріоритетних напрямів діяльності держави та суспільства щодо розвитку громадянина як високоморальної особистості, яка плекає українські традиції, духовні цінності, володіє 


\section{ЗМІСТОВІ КОМПОНЕНТИ НАЦІОНАЛЬНО-ПАТРІОТИЧНОГО ВИХОВАННЯ УЧНІВСЬКОЇ МОЛОДІ}

відповідними знаннями, вміннями та навичками, здатна реалізувати свій потенціал в умовах сучасного суспільства, сповідує європейські цінності, готова до виконання обов'язку із захисту Батьківщини, незалежності та територіальної цілісності України" [10, 1]. Тому фахівці увиразнюють змістові аспекти національнопатріотичного виховання, зосереджуючись на формуванні учнівської молоді, високих громадянських якостей, що $є, 3$ одного боку, системним процесом і стрижневим конструктом, а 3 іншого, - провідним чинником в ієрархії цінностей. Очевидно, цей напрям виховання $\epsilon$ надзвичайно важливим і перспективним.

Аналіз останніх досліджень і публікацій. Проблеми національно-патріотичного виховання дітей та молоді досліджують сучасні вчені I. Бех, О. Вишневський, М. Євтух, О. Киричук, О. Коберник, П. Кононенко, М. Красовицький, В. Кузь, Н. Мойсеюк, Л. Новікова, Н. Селіванова, Б. Ступарик, М. Чепіль, К. Чорна та ін. Науковці одностайно визнають, що надважливими завданнями сучасних освітян $є$ формування в учнівської молоді системи патріотичних цінностей і переконань, створення відповідного виховного простору для розвитку в неї громадянських почуттів та прищеплення високоморальних гуманістичних ідеалів.

Питання національно-патріотичного виховання учнівської молоді широко висвітлювалося у науковій літературі, проте його змістові аспекти 3'ясовані недостатньо. Відтак, усвідомлюючи пріоритетність зазначеної виховної компоненти, метою статті $€$ аналіз основних змістових аспектів національно-патріотичного виховання учнівської молоді.

Виклад основного матеріалу дослідження 3 повним обгрунтуванням отриманих наукових результатів. Для сучасного демократичного Українського суспільства проблема національнопатріотичного виховання школярів стає все більш актуальною, оскільки вони не усвідомлюють свого “коріння”, не знають як слід своєї історії $\mathrm{i}$, як наслідок, не прагнуть змінити життя країни на краще. У контексті подальшої розбудови нашої незалежної держави дедалі затребуванішим стає формування “мегаактивної” особистості учняпатріота, від діяльності якого у майбутньому значною мірою залежатиме духовний розвиток i добробут України. Тому не випадково у наукових колах визріла ідея створення Стратегії національно-патріотичного виховання дітей та молоді на 2016 - 2020 роки, котра б визначала його компоненти, а також передбачала засоби підвищення духу та громадянської активності юних українців. Як слушно зазначає М. Чепіль, “...новому періодові розвитку держави має відповідати нова філософія освіти і виховання, нові моделі навчання, спрямовані на формування національної свідомості й самосвідомості, виховання національного типу особистості" $[11,39]$.

Серед сучасних вітчизняних науковців усе чіткіше увиразнюється нове бачення змісту патріотичного виховання учнівської молоді, як важливої складової національного виховання. Головною метою фахівці проголошують становлення самодостатнього громадянина патріота України, гуманіста й демократа, готового до виконання громадянських і конституційних обов'язків, до успадкування багатих духовних та культурних надбань українського народу, до високої культури міжособистісних взаємин. Загалом патріотичне виховання сприяє національному єднанню, зміцненню соціальноекономічних, духовних та культурних підвалин вітчизняного суспільства [8].

На думку О. Вишневського, національнопатріотичне виховання грунтується на таких цінностях, як: українська ідея, державна незалежність, національна гідність, історична пам'ять, пошана до національної культури, мови, символів, до Конституції, конструктивна участь у державотворчих процесах тощо $[2,188]$. Національно-патріотичне виховання, поєднуючись із моральним, $є$ підвалиною вітчизняного складає зміст нашого виховного ідеалу: “Служіння Богові й Україні” [Там само, 189].

У Стратегії національно-патріотичного виховання дітей та молоді на 2016 - 2020 роки виокремлено такі його три компоненти: громадянсько-патріотичний; військово-патріотичний; духовно-моральний [10], розкриваючи їх сутність та зміст виховної діяльності серед школярів у загальноосвітніх закладах України.

Одним із надзвичайно важливих напрямів педагогічної роботи в сучасній школі $\epsilon$ громадянське виховання, яке сприяє формуванню свідомого українця, людини 3 притаманними їй високоморальними особистісними якостями й рисами характеру, гуманістичним світоглядом і способом мислення, спрямованими на розвиток демократичного вітчизняного суспільства. Головна мета громадянсько-патріотичного виховання - підготовка молоді до життя у правовій незалежній країні, у взаємопов'язаному світі, визнання та прийняття його загальнолюдських цінностей, формування громадянської позиції кожного учня [9].

Проте, на нашу думку, громадянськопатріотичне виховання передбачає й вироблення 
в особистості чіткого уявлення про закономірності розвитку патріотичних ідей, розуміння ролі історичних знань про свою країну, народ, його традиції та звичаї, формування стійких патріотичних переконань і вміння відстоювати їх в умовах реальної дійсності.

Ще починаючи з Революції Гідності, в одному 3 Міністерських листів було зазначено, що в сучасних загальноосвітніх вітчизняних закладах патріотичне виховання має наскрізно охоплювати весь навчально-виховний процес, органічно поєднуючи національну, громадянську, моральну, родинно-сімейну, естетичну, правову, економічну, фізичну, трудову компоненти базуючись на національній історії, знанні і відстоюванні своїх прав, виконанні конституційних та громадянських обов' язків, а також на відповідальності за власне майбутнє, добробут і долю своєї країни $[7,1]$.

Так було створено цілісну концепцію громадянсько-патріотичного виховання у загальноосвітніх закладах, котра сьогодні здійснюється шляхом реалізації низки виховних завдань, а саме:

- забезпечення сприятливих умов для самореалізації особистості в умовах вітчизняного соціуму відповідно до іï інтересів та можливостей;

- виховання правової культури, поваги до Конституції України, їі Законів, державної символіки - Герба, Прапора, Гімну України та їі історичних святинь;

- сприяння набуттю соціального досвіду, успадкуванню молоддю духовних та культурних надбань українського народу;

- оволодіння рідною мовою; розвиток мовної культури, вживання української мови як духовного коду нації;

- формування духовних цінностей українського громадянина: почуття патріотизму, національної свідомості, любові до Батьківщини рідного народу, його історії, своїх землі й родини, гордості за минуле і сучасне Української Держави на прикладах іiі героїчної історії та кращих зразків культурної спадщини;

- відновлення і вшанування національної пам'яті;

- утвердження у свідомості громадян об'єктивної оцінки ролі українського війська у вітчизняній історії, спадкоємності розвитку Збройних Сил у відстоюванні ідеалів свободи та державності України - від Княжої доби, Гетьманського козацького війська, військ Української народної республіки (УНР), Січових стрільців (УСС), Української повстанської армії (УПА) до часів незалежності;

- вироблення психологічної та фізичної готовності молоді до виконання громадянського і конституційного обов'язку щодо відстоювання національних інтересів та незалежності держави; підвищення престижу державної та військової служби і розвиток мотивації молоді до них;

- відродження та розвиток українського козацтва як важливої громадської сили військовопатріотичного виховання молоді;

- забезпечення духовної єдності поколінь; виховання поваги до батьків, осіб похилого віку; турбота про молодших та людей з особливими потребами;

- сприяння діяльності установ, навчальних закладів, організацій, клубів та осередків громадської активності, причетних до патріотичного виховання молоді;

- підтримання кращих рис української нації працелюбності, прагнення до свободи, любові до природи та мистецтва, поваги до батьків і родини;

- створення умов для розвитку громадянської активності, професіоналізму, високої мотивації до праці як основи конкурентоспроможності громадянина, а відтак, і держави;

- виховання здатності протидіяти проявам аморальності, правопорушень, бездуховності, антигромадської діяльності тощо [6].

Другою важливою складовою патріотичного виховання є військово-патріотична компонента, зміст якої визначається Конституцією та законами України, військовою Присягою та військовими статутами. Військово-патріотичне виховання орієнтоване на формування готовності до військової служби як особливого виду державної праці. Пропонуємо ще й визначення В. Івашковського: “Військово-патріотичне виховання - це різноманітна, систематична, цілеспрямована та скоординована діяльність державних органів, громадських об'єднань та організацій щодо формування у молоді високої патріотичної свідомості, почуття вірності своїй Вітчизні, готовності до виконання громадянського та конституційного обов'язку щодо захисту інтересів Батьківщини" [5, 33].

3 огляду на предмет нашого дослідження нам найбільше імпонує погляд на військовопатріотичне виховання як на “...цілеспрямований, організований процес формування готовності учнів старших класів до строкової військової служби в Збройних Силах України" [3]

Метою військово-патріотичного виховання науковці проголошують розвиток у молоді громадянськості, патріотизму як найважливіших духовно-моральних і соціальних цінностей; формування в неї професійно значущих якостей, умінь та готовності до їх активного прояву у 


\section{ЗМІСТОВІ КОМПОНЕНТИ НАЦІОНАЛЬНО-ПАТРІОТИЧНОГО ВИХОВАННЯ УЧНІВСЬКОЇ МОЛОДІ}

різноманітних галузях життя суспільства, зокрема у військовій та інших, пов'язаних із нею, видах державної служби; вірності конституційному та військовому обов'язку за умов мирного i воєнного часу; високої відповідальності та дисциплінованості.

Досягнення зазначеної мети передбачає реалізацію таких завдань:

- проведення науково обгрунтованої управлінської та організаторської роботи зі створення умов для ефективного військово-патріотичного виховання молоді;

- виховання в учнівської молоді патріотичних цінностей, поглядів та переконань; поваги до культурного й історичного минулого України, до традицій державної, особливо військової служби; підвищення їх престижу;

- створення нової ефективної системи військово-патріотичного виховання, яка б сприяла формуванню у молоді відданості Вітчизні, готовності до гідного служіння суспільству та державі, а також сумлінному виконанню службових обов'язків;

- вироблення механізму, здатного забезпечити ефективне функціонування цілісної системи військово-патріотичного виховання молоді, в тому числі й тієї, яка перебуває на дійсній військовій службі у Збройних силах України, інших військових формуваннях та органах $[5,33]$.

Не менш актуальним й на часі виокремлення поняття героїко-патріотичне виховання, що передбачає прищеплення високих ідеалів служіння народові, готовності до трудових та героїчних звершень заради процвітання Української держави. Орієнтоване на знаменні історичні дати, воно виховує гордість за славні подвиги наших героїчних предків. Крім того, героїко-патріотичне виховання покликане формувати громадянинапатріота; виробляти у нього глибоке розуміння громадянського обов'язку, готовності в будь-який час стати на захист Батьківщини; оволодівати військовими і військово-технічними знаннями; спонукати до фізичного самовдосконалення, а також ознайомлення з бойовими традиціями та героїчними сторінками історії українського народу, його Збройних Сил [4].

Третім (і останнім) чинником національнопатріотичного виховання є духовно-моральне виховання. На думку І. Беха, “....моральнодуховна вихованість підростаючої особистості нині є пріоритетною метою всієї освітньої системи. Ішкола, як одна із соціальних інституцій, що причетна до процесу виховання, має орієнтуватися на такі чотири рівні моральнодуховного зростання людини:
1. Субстанційний, що розкриває першопричину морально-духовного поступу.

2. Структурний, який визначає єдність емоцій і різної предметності (змістовості).

3. Темпоральний, котрий утверджує лінійність (розгортання) і циклічність (функціонування) духовного розвитку особистості.

4. Особистісний, який висвітлює прогресивні зміни морально-духовних актів за допомогою розгортання рефлексії та волі суб'єкта..." [1, 18 - 19]. Тому одним із механізмів становлення особистості постає саморегуляція ії мотивації до ціннісних орієнтацій духовно-морального змісту.

Духовно-моральне виховання спрямоване на усвідомлення учнями вищих цінностей, ідеалів і орієнтирів, соціально-значущих процесів та явищ реального життя; виховання любові до рідного слова, рідної мови, літератури й культури. Якщо таке виховання підкріплюють відповідними настановами, спонуканням до добрих справ, у серці школярів утверджуються внутрішні духовні сили, сприяючи формуванню громадянської порядності. Отже, рівень духовності визначає життя особистості, і значною мірою - майбутне української нації. Адже загальновідомо, що моральність нації- це основа їі духовної стійкості та спадкоємності історичного буття.

Отже, актуальним є формування у нового покоління патріотичної свідомості, вірності своїй Вітчизні, готовності до виконання громадянських і конституційних обов'язків, до строкової військової служби у Збройних Силах України, до успадкування багатих духовних і культурних надбань українського народу, усвідомлення гуманістичних цінностей, ідеалів та орієнтирів, соціально-значущих процесів і явищ реального життя, любов до рідного слова, рідної мови, літератури, а також досягнення високої культури взаємин.

Висновки. Основна мета діяльності вітчизняних загальноосвітніх шкіл полягає у формуванні в учнівської молоді чіткої громадянської позиції; соціально-патріотичної поведінки; готовності до відповідної діяльності в будь-яких обставинах; високої культури міжособистісних відносин; пізнання глибинного пласту національної культури; формування потреби працювати задля розквіту держави, готовності її захищати. Школам необхідно широко пропагувати зміст національно-патріотичного виховання, що є суттєво значущим у становленні майбутніх відповідальних громадян нашої держави, спроможних виборювати національну ідентичність, формуючи власну свідомість та самосвідомість 
Перспективними напрямами майбутніх досліджень вважаємо аналіз методів національнопатріотичного виховання учнівської молоді у виховній роботі сучасної вітчизняної загальноосвітньої школи.

\section{ЛITEPAТУРА}

1. Бех І. Д. Виховання особистості: Сходження до духовності: наук. Видання / І.Д. Бех. - К.: Либідь, 2006. -272 c.

2. Вишневський О. Українська освіта на шляху реформ / О. Вишневський. - Дрогобич: Швидкодрук, 2013. -448 c.

3. Військово-патріотичне виховання молоді у школі [Електронний ресурс] / Режим доступу: http:// www.glukhiv-osvita.sumy.sch.in.ua/robota viddilu/ storinka_metodista/vihovna_robota/vijsjkovopatriotichne vihovannya/?pvi=pvi

4. Героїко-патріотичне виховання школярів [Електронний ресурс] / Режим доступу: http:// klasnaocinka.com.ua/ru/article/-geroyiko-patriotichnevikhovannya-shkolyariv.html

5. Івашковський В. Концепція військово-патріотичного виховання молоді України / В. Івашковський // Теорія та методика хортингу. - 2014. - № 2. - С. $28-45$.

6. Концепція національно-патріотичного виховання школярів [Електронний ресурс] / Режим доступу: pomichna-school2.edukit.kr.ua/.../громадянсько\%20патріотичне \%20виховання.do..

7. Методичні рекомендації 3 організації патріотичного виховання дітей та учнівської молоді у 2014/2015 навчальному році: (додаток до листа Міністерства освіти і науки України від 27.11.2014 p. № 1/9-614) [Електронний ресурс] / Режим доступу: http://osvita.ua/legislation/pozashk_osv/44204/

8. Національно-патріотичне виховання [Електронний pecypc] / Режим доступу: http://cls.ks.ua/chitacham/ informacijni-vidannya-ibv/help/technology/patriot

9. Пріоритетні напрями громадянського виховання в сучасній школі [Електронний ресурс] // Режим доступу: http://osvita.ua/school/lessons summary/ upbring/36173/

10. Стратегія національно-патріотичного виховання дітей та молоді на 2016 - 2020 роки: Указ Президента України від 13 жовтня 2015 року № 580/2015 [Електронний ресурс] // Режим доступу: http:// www.president.gov.ua/ documents/ 5802015-19494.

11. Чепіль М.М. Теоретико-методологічні аспекти патріотичного виховання / М.Чепіль // Проблеми українського національного виховання: зб. наук. пр. / за ред. Н. Скотної та М. Чепіль. - Дрогобич: Редакційно-видавничий відділ Дрогобицького державного педагогічного університету імені Івана Франка, 2013. - С. 34 - 43.

\section{REFERENCES}

1. Bekh, I.D. (2006). Vykhovannia osobystosti: Skhodzhennia do dukhovnosti [Raising a Personality: Climbing to Spirituality]. Kyiv: Lybid, 272 p. [in Ukrainian].
2. Vyshnevskyi, O. (2013). Ukrainska osvita na shliakhu reform [Ukrainian Education on the Way of Reform]. Drohobych: Shvydkodruk, 448 p. [in Ukrainian].

3. Viiskovo-patriotychne vykhovannia molodi u shkoli [Military-patriotic upbringing of youth at school]. [Electronic resourse]. Available at: http://www.glukhivosvita.sumy.sch.in.ua/robota viddilu/ storinka_metodista/vihovna_robota/ vijsjkovopatriotichne vihovannya/?pvi $=$ pvi $\quad$ in Ukrainian].

4. Heroiko-patriotychne vykhovannia shkoliariv [Heroic-patriotic education of schoolchildren]. [Electronic resourse]. Available at: http:// klasnaocinka.com.ua/ru/article/-geroyiko-patriotichnevikhovannya-shkolyariv.html[in Ukrainian].

5. Ivashkovskyi, V. (2014). Kontseptsiia viiskovopatriotychnoho vykhovannia molodi Ukrainy [Concept of military-patriotic education of Ukrainian youth]. The theory and method of horting, no. 2, pp. $28-45$. [in Ukrainian].

6. Kontseptsiia natsionalno-patriotychnoho vykhovannia shkoliariv [Concept of national-patriotic education of schoolchildren]. [Electronic resourse]. Available at: pomichna-school2.edukit.kr.ua/.../громадянсько $\% 20$ патріотичне\% \%20виховання.do... [in Ukrainian].

7. Metodychni rekomendatsii z orhanizatsii patriotychnoho vykhovannia ditei ta uchnivskoi molodi u 2014/2015 navchalnomu rotsi [Methodical recommendations on the organization of patriotic education of children and pupils in the 2014/2015 academic year]: (dodatok do lysta Ministerstva osvity i nauky Ukrainy vid 27.11.2014 r. № 1/9-614) [Electronic resourse]. Available at: :http://osvita.ua/legislation/ pozashk_osv/44204/[in Ukrainian].

8. Natsionalno-patriotychne vykhovannia [National patriotic education]. [Electronic resourse]. Available at: http://cls.ks.ua/chitacham/informacijni-vidannya-ibv/ help/technology/patriot [in Ukrainian].

9. Priorytetni napriamy hromadianskoho vykhovannia $\mathrm{v}$ suchasnii shkoli [Priority directions of civic education in modern school]. [Electronic resourse]. Available at: http://osvita.ua/school/lessons_summary/upbring/ 36173/[in Ukrainian].

10. Stratehiia natsionalno-patriotychnoho vykhovannia ditei ta molodi na 2016 - 2020 roky [Strategy of nationalpatriotic upbringing of children and youth for 20162020]. Ukaz Prezydenta Ukrainy vid 13 zhovtnia 2015 roku № 580/2015 [Electronic resourse]. Available at: http://www.president.gov.ua/ documents/ 580201519494. [in Ukrainian].

11. Chepil, M.M. (2013). Teoretyko-metodolohichni aspekty patriotychnoho vykhovannia [Theoretical and methodological aspects of patriotic education]. The problems of Ukrainian of Ukrainian National Education: A collection of scientific works N. Skotna \& M. Chepil (Eds.). Drohobych: DSPU Publ., pp.34 43. [in Ukrainian].

Стаття надійшла до редакції 05.02.2018 